Original article

\title{
Radial variations in wood mineral element concentrations: a comparison of beech and pedunculate oak from the Belgian Ardennes
}

\author{
Valérie Penninckx, Suzanne Glineur, Wolf Gruber, Jacques Herbauts* and Pierre Meerts \\ Laboratoire de génétique et d'écologie végétales, Université Libre de Bruxelles, \\ Chaussée de Wavre 1850, 1160 Bruxelles, Belgium
}

(Received 20 June 2000; accepted 25 September 2000)

\begin{abstract}
Radial variations in wood mineral element concentrations (N, P, Ca, Mg, K, Mn, Al) were investigated in 5 oak trees (a ring-porous species with typical heartwood) and 5 beech trees (a diffuse-porous to semi-ring porous wood species lacking typical heartwood) growing on an ochreous brown earth in the Belgian Ardennes. Differences in concentration profiles were consistent with the difference in wood structure. Specifically, oak had markedly higher concentrations in sapwood, suggesting that nutrients are actively resorbed from senescing wood rings, resulting in very low elemental concentrations in heartwood. Similarities between the two species, including outwardly decreasing cation concentrations and a recent increase in Al concentration, might be ascribed to a common environmental influence, i.e. soil leaching by acid rain. However, the decrease in Mn concentration in both species is not consistent with a scenario of decreasing soil $\mathrm{pH}$. Alternative explanations are discussed.
\end{abstract}

dendrochemistry / heartwood / sapwood / Fagus sylvatica / Quercus robur / beech / oak / soil acidification

Résumé - Variations radiales des concentrations en éléments minéraux du bois : une comparaison entre hêtre et chêne pédonculé en Ardenne belge. Les variations radiales des teneurs en éléments minéraux ( $\mathrm{N}, \mathrm{P}, \mathrm{Ca}, \mathrm{Mg}, \mathrm{K}, \mathrm{Mn}, \mathrm{Al})$ ont été mesurées dans 5 chênes (une essence à anneaux poreux et à bois de cœur bien différencié) et 5 hêtres (une essence à porosité diffuse et dépourvue de bois de cœur bien différencié) croissant sur sol brun ocreux dans le massif ardennais belge. Les différences dans les profils dendrochimiques sont conformes aux différences structurales du bois. Chez le chêne, les concentrations sont nettement plus élevées dans l'aubier, ce qui suggère une résorption active des éléments minéraux au cours du vieillissement des cernes, avec pour conséquence des concentrations extrêmement faibles dans le bois de cœur. Des convergences entre les deux espèces - notamment une apparente diminution des concentrations en cations (dans le bois de cœur pour le chêne, tout au long de la chronologie pour le hêtre) accompagnée d'une augmentation récente des teneurs en aluminium - pourraient être attribuées à une influence environnementale commune, par exemple une désaturation du sol sous l'influence de pluies acides. Cependant, la diminution des teneurs en manganèse enregistrée chez les deux essences ne conforte pas l'hypothèse d'une acidification du sol. D'autres hypothèses sont discutées.

dendrochimie / bois de cour / aubier / Fagus sylvatica / Quercus robur / hêtre / chêne / acidification du sol

\section{INTRODUCTION}

Mineral element concentrations in wood are not constant across growth rings. It has been proposed that variations in the mineral element composition of tree rings might reflect corresponding changes in the soil solution chemistry in the course of a tree's lifetime. Thus, a growing amount of evidence suggests that soil acidification due to atmospheric pollution ("acid rain") leads to decreasing concentrations of calcium and magnesium

* Correspondence and reprints

Tel. (32) 02672 4518; Fax. (32) 02672 0284; e-mail: jherbaut@ulb.ac.be 
and increasing concentration of aluminium in the wood $[4,8,18,20,22]$. However, non-uniform radial concentration profiles in the wood may also result from endogenous mechanisms not related to environmental change $[6,9,12,23,29,31,34]$ and, accordingly, monitoring metal pollution using tree rings composition can be extremely difficult [14]. For instance, radial translocations of elements can occur when essential elements are resorbed from senescing wood at the time of heartwood formation. Resorption of essential nutrients from senescing growth rings significantly contributes to the internal cycling of these elements within a tree, thereby reducing the amounts of elements that have to be absorbed annually from the soil $[2,10,33]$. Clearly, the use of dendrochemistry as a biomonitoring tool of environmental change, requires that endogenous signals and environmentally induced variations in wood elemental concentrations can be distinguished [9, 14].

In this paper, we compare radial patterns in mineral element concentrations in Pedunculate oak (Quercus robur L.) and European beech (Fagus sylvatica L.) growing at the same site. Beech and oak are dominant trees in several forest types in Central and Western Europe and often occur in mixed stands. These species markedly differ in wood structure. Specifically, oak is a ring-porous species possessing typical heartwood [3, 28], while beech is a diffuse-porous to semi-ring porous species lacking typical heartwood [28, 30]. In a recent study, Lévy et al. [18] have ascribed patterns of elemental concentrations variation in the last thirty years of the heartwood of oak from NE France to soil acidification. By contrast, beech is not usually regarded as suitable for dendrochemical biomonitoring because of radial translocations of elements [14]; accordingly, the dendrochemistry of beech has been surprisingly little investigated, considering its importance in European forests (but see $[15,22])$.

The study site is situated in the Belgian Ardennes massif, characterised by acid soils with a very low calcium level; these soils are thus susceptible to acidification by atmospheric pollution. Forest decline is well documented in that region [32].

In this work, we assume that any difference in the radial profiles of mineral element concentrations between beech and oak in the same site would primarily reflect physiological differences pertaining to heartwood formation. By contrast, similarities in the patterns of variation of elemental concentrations in two species with contrasting wood structure might be indicative of a common environmental influence.

\section{MATERIALS AND METHODS}

\subsection{Site description}

The forest stand selected for this study is located in the Herbeumont State Forest (I.G.N. map grid reference: Herbeumont-Suxy 67/3-4, 49 $48^{\prime} \mathrm{N}, 5^{\circ} 16^{\prime} \mathrm{E}$ ). This forest covers 1543 ha of a $400 \mathrm{~m}$ height plateau, between Semois and Vierre river valleys, in the southern part of the Belgian Ardennes. Average annual rainfall amounts to $1200 \mathrm{~mm}$ and mean annual temperature is $7.8^{\circ} \mathrm{C}$. The bedrock consists of Lower Devonian clastic rocks, mainly Gedinnian siliceous sandstones and slates.

The studied forest stand is a selection high-forest of beech and pedunculate oak (Quercus robur L.); beech is clearly the dominant species, apparently impairing the natural regeneration of oak. The floristic composition of the herbaceous layer is characteristic of the LuzuloFagetum forest association with acidity indicators including Luzula luzuloides (Lam.) Dandy et Wilmott, Deschampsia flexuosa (L.) Trin., Carex pilulifera L. and Polytrichum formosum Hedw. The soil, with an $\mathrm{A}_{\mathrm{h}} \mathrm{B}_{\mathrm{w}} \mathrm{C}$ profile, is an ochreous brown earth (USDA: Dystrochrept; FAO/UNESCO: Dystric Cambisol); the humus is of the moder type $(\mathrm{C} / \mathrm{N}=16.8)$. The parent material is a loamy and stony solifluxion layer, about 1 to $1.5 \mathrm{~m}$ thick, in which weathering products of the bedrock (Gedinnian sandstones and slates) have been mixed with addition of allochtonous loess. Silt-size particles $(2-50 \mu \mathrm{m})$ are therefore prevailing in the mineral soil fractions, amounting to more than $50 \%$ (table I); the clay content $(<2 \mu \mathrm{m})$ is around $15 \%$ and is uniformly distributed throughout the profile, whereas the sand fraction (20-30\%) slightly increases with depth. The gravel fraction $(>2 \mathrm{~mm})$ is around $20 \%$ in weight in all horizons. Soil borings as well as data provide by the Soil Map of Belgium (unpublished sheet Herbeumont 213W, surveyed at the scale of 1:5000) show that the parent material is homogeneous all over the sampling area. Soil acidity is strong in mineral horizons (cambic $\mathrm{B}_{\mathrm{w}}$ and $\mathrm{C}$ horizons: $\mathrm{pH}-\mathrm{H}_{2} \mathrm{O}$ around 4.5) and very strong in the humic layer $\left(\mathrm{A}_{\mathrm{h}}\right.$ horizon: $\left.\mathrm{pH}-\mathrm{H}_{2} \mathrm{O}<4.0\right)$, corresponding to very low effective cation saturation rates $(<10 \%)$ and very high saturation rates of exchangeable aluminium (mostly >90\%) (table I). Very low levels of total calcium, magnesium and potassium $(\mathrm{CaO}<0.03 \% ; \mathrm{MgO}=$ $1.1 \% ; \mathrm{K}_{2} \mathrm{O}=2.4 \%$ ) in the siliceous-rich Gedinnian bedrock $\left(\mathrm{SiO}_{2}=74 \%\right)$ are critical to explain a deficiency of base cations in the soil. 


\subsection{Sampling}

Five beech and five pedunculate oak trees (130-160 years old) were randomly sampled in the mixed stand, on the occasion of a forest clearing during the 1997 winter. Discs of about $10 \mathrm{~cm}$ in thickness were cut off from the top of the boles (i.e. at a height of about $10-12 \mathrm{~m})$. The samples were used for dendroecological and dendrochemical measurements. The size of the sample is in the range of recent dendrochemical investigations (e.g. $[6,11,15,16,22,24,26])$.

\subsection{Sample preparation and analytical methods}

The discs were polished to reveal annual growth rings, using a sand-papering machine fitted up with a silicium-carbide band, to avoid aluminium contamination by usual corundum abrasives. For each disc, wood samples representing 5-year growth intervals were cut off with a band saw and a chisel. The samples were dried at $65^{\circ} \mathrm{C}$ and ground in a Retsch ZM100 mill to pass a $750 \mu \mathrm{m}$ screen. Mineralization of about $1 \mathrm{~g}$ sample was done by dry ashing in covered zirconium crucibles $(16 \mathrm{~h}$ at $450{ }^{\circ} \mathrm{C}$ ); ashes were dissolved with $1 \mathrm{ml}$ suprapur $\mathrm{HCl}$ (diluted 1/2) and heated on a hot plate for 10 minutes, avoiding boiling; $1 \mathrm{ml}$ suprapur $\mathrm{HNO}_{3}$ is added to this solution and made up to a final volume of $100 \mathrm{ml}$. Ca, $\mathrm{Mg}, \mathrm{K}$ and $\mathrm{Mn}$ were determined by flame atomic absorption spectrometry (FAAS), Al by electrothermal atomic absorption spectrometry (EAAS) and P by colorimetry (Scheel Method [7]). N was determined by the semimicro Kjeldahl method.

\section{RESULTS}

In oak, all elements show higher concentrations in the last 25 to 35 growth rings (15 years for $\mathrm{Al}$ ), roughly corresponding to sapwood (figure 1): a visual examination of the cores shows that the sapwood is made up of 23 to 32 annual rings. A very steep increase in concentration at the sapwood/heartwood boundary is observed for P, K, $\mathrm{N}, \mathrm{Ca}$ and $\mathrm{Mg}$. Concentration ratios between the outermost heartwood rings and the outermost sapwood rings vary depending on element as follows: N: $50 \%, \mathrm{P}: 12 \%$, Ca: $40 \%, \mathrm{Mg}: 5 \%, \mathrm{~K}: 45 \%, \mathrm{Mn}: 15 \%$.

In oak heartwood, all elements except $\mathrm{N}$ show outwardly decreasing concentrations and this is significant for $\mathrm{Ca}(r=-0.79, p<0.01), \mathrm{Mg}(r=-0.91, p<0.001)$, $\mathrm{K}(r=-0.94, p<0.001), \mathrm{Mn}(r=-0.70, p<0.05)$ and $\mathrm{P}(r=-0.86, p<0.001)(n=11$ for all elements $)$.

Table I. Soil analytical data of the studied forest stand.

\begin{tabular}{|c|c|c|c|c|c|c|c|c|c|}
\hline \multirow[t]{2}{*}{ Horizons } & \multirow{2}{*}{$\begin{array}{l}\text { Depth } \\
(\mathrm{cm})\end{array}$} & \multicolumn{4}{|c|}{ Particle size distribution (\%) } & \multirow[t]{2}{*}{ O.M. $(\%)$} & \multirow[t]{2}{*}{$\mathrm{N}(\%)$} & \multirow[t]{2}{*}{$\mathrm{C} / \mathrm{N}$} & \multirow{2}{*}{$\mathrm{pH}-\mathrm{H}_{2} \mathrm{O}$} \\
\hline & & $2000-50 \mu \mathrm{m}$ & $50-20 \mu \mathrm{m}$ & $20-2 \mu \mathrm{m}$ & $<2 \mu \mathrm{m}$ & & & & \\
\hline $\mathrm{A}_{\mathrm{b}}$ & $0-3$ & & & & & 36.1 & 1.07 & 16.8 & 3.2 \\
\hline $\mathrm{A}_{\mathrm{h}}^{\mathrm{n}} / \mathrm{B}_{\mathrm{w}}$ & $3-10$ & 22.4 & 17.5 & 35.6 & 24.5 & 12.5 & 0.41 & 15.1 & 3.5 \\
\hline $\mathrm{B}_{\mathrm{w} 1}^{\mathrm{w}}$ & $15-25$ & 19.6 & 21.2 & 43.4 & 15.8 & 5.2 & 0.20 & 13.0 & 4.2 \\
\hline $\mathrm{B}_{\mathrm{w} 2}^{\mathrm{w1}}$ & $25-35$ & 23.6 & 21.3 & 39.6 & 15.4 & 3.1 & 0.15 & 10.6 & 4.4 \\
\hline $\mathrm{B}_{\mathrm{w}}^{\mathrm{w}} / \mathrm{C}$ & $45-55$ & 24.8 & 24.6 & 37.5 & 13.1 & 1.1 & 0.09 & 5.9 & 4.6 \\
\hline $\mathrm{C}_{1}^{\mathrm{W}}$ & $60-80$ & 25.3 & 24.2 & 36.5 & 14.0 & 0.6 & 0.07 & nd & 4.6 \\
\hline $\mathrm{C}_{2}^{1}$ & $80-100$ & 30.3 & 21.0 & 34.5 & 14.2 & 0.3 & nd & nd & 4.6 \\
\hline $\mathrm{C}_{3}^{2}$ & $120-140$ & 32.5 & 24.1 & 28.3 & 15.2 & 0.5 & nd & nd & 4.3 \\
\hline \multirow[t]{2}{*}{ Horizons } & Exchange & \multirow{2}{*}{\multicolumn{3}{|c|}{$\begin{array}{c}\text { Exchangeable cations } \\
\mathrm{Ca}^{++} \\
\mathrm{Mg}^{++}\end{array}$}} & Exch. & Exch. & Effective & Effective & Aluminium \\
\hline & $\begin{array}{c}\operatorname{acidity}^{(\mathrm{a})} \\
\left(\mathrm{cmol}_{\mathrm{c}} \mathrm{kg}^{-1}\right)\end{array}$ & & & & $\begin{array}{c}\mathrm{Al}^{3+(\mathrm{a})} \\
\left(\mathrm{cmol}_{\mathrm{c}} \mathrm{kg}^{-1}\right)\end{array}$ & $\begin{array}{c}\mathrm{Mn}^{++}(\mathrm{b}) \\
\left(\mathrm{cmol}_{\mathrm{c}} \mathrm{kg}^{-1}\right)\end{array}$ & $\begin{array}{c}\mathrm{CEC} \\
\left(\mathrm{cmol}_{\mathrm{c}} \mathrm{kg}^{-1}\right)\end{array}$ & $\begin{array}{l}\text { saturation } \\
\text { rate }(\%)\end{array}$ & $\begin{array}{l}\text { saturation } \\
\text { rate }(\%)\end{array}$ \\
\hline $\mathrm{A}_{\mathrm{h}}$ & 9.97 & 1.55 & 0.59 & 0.41 & 7.65 & 0.40 & 12.52 & 20.3 & 61.1 \\
\hline $\mathrm{A}_{\mathrm{h}} / \mathrm{B}_{\mathrm{w}}$ & 11.01 & 0.23 & 0.19 & 0.14 & 9.50 & 0.04 & 11.57 & 4.9 & 82.1 \\
\hline $\mathrm{B}_{\mathrm{w} 1}$ & 5.21 & 0.11 & 0.06 & 0.04 & 5.14 & 0.03 & 5.43 & 4.1 & 94.6 \\
\hline$B_{w 2}^{w 1}$ & 3.29 & 0.10 & 0.04 & 0.02 & 3.29 & 0.03 & 3.46 & 4.9 & 95.1 \\
\hline $\mathrm{B}_{\mathrm{w}}^{\mathrm{w}} / \mathrm{C}$ & 2.90 & 0.07 & 0.03 & 0.03 & 2.90 & 0.02 & 3.02 & 4.1 & 95.9 \\
\hline $\mathrm{C}_{1}^{\mathrm{w}}$ & 4.24 & 0.08 & 0.04 & 0.05 & 4.24 & 0.02 & 4.40 & 3.8 & 96.2 \\
\hline $\mathrm{C}_{2}^{1}$ & 4.76 & 0.11 & 0.04 & 0.09 & 4.76 & 0.02 & 4.99 & 4.7 & 95.3 \\
\hline $\mathrm{C}_{3}^{2}$ & 5.00 & 0.13 & 0.05 & 0.08 & 5.00 & 0.02 & 5.25 & 4.9 & 95.1 \\
\hline
\end{tabular}

(a) $\mathrm{KCl} \mathrm{N}$ extraction. (b) $\mathrm{CH}_{3} \mathrm{COONH}_{4}$-EDTA pH 4.65 extraction. 

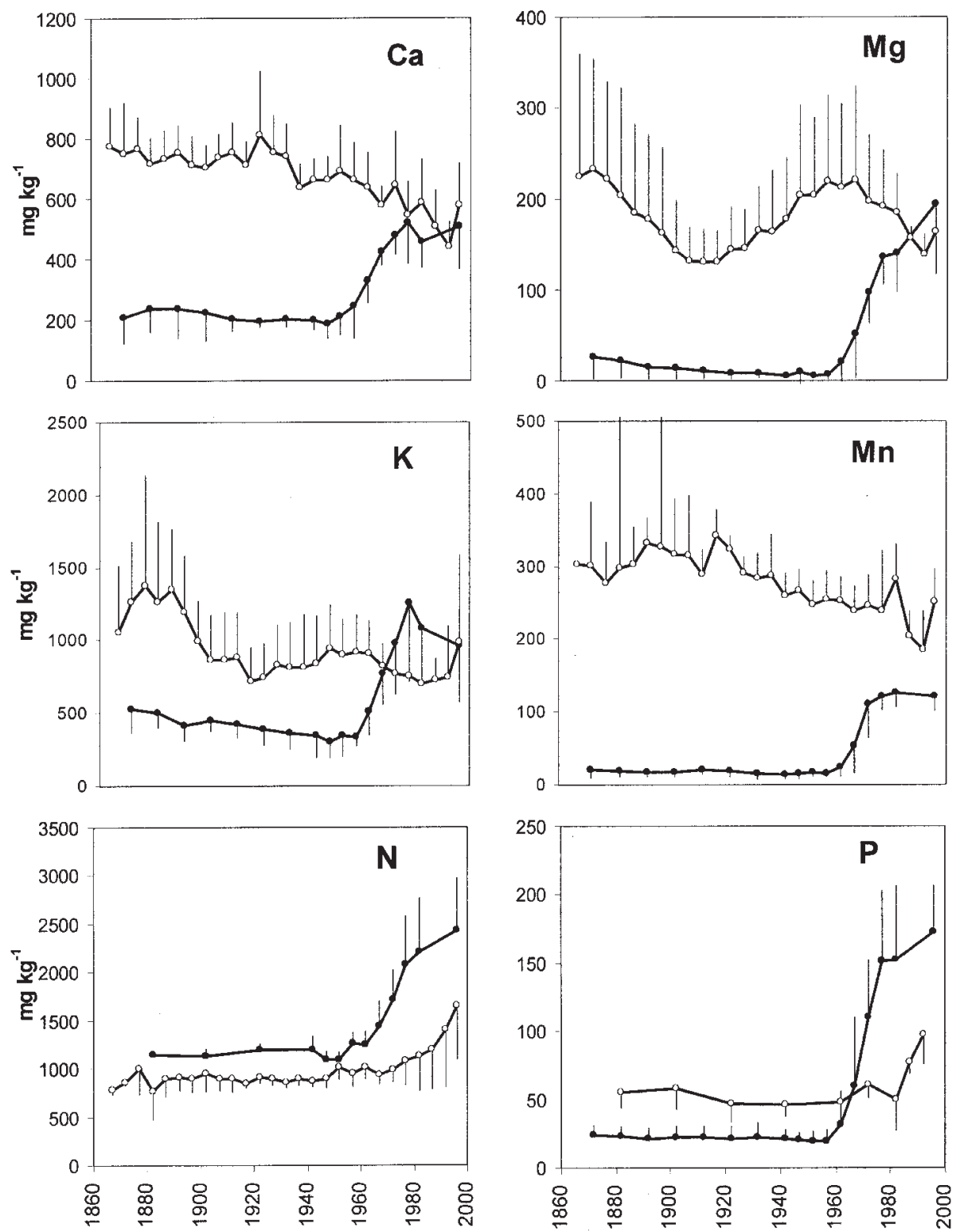

Figure 1. Wood element concentrations in 5-year growth intervals in Fagus sylvatica L. (white dots) and Quercus robur L. (black dots) (mean and standard deviation over five individuals).

In beech, element concentration profiles are quite different than in oak (figure 1). Overall, beech wood is considerably richer in mineral elements than oak heartwood, the difference being most striking for $\mathrm{Mg}, \mathrm{Mn}$ and $\mathrm{Ca} . \mathrm{N}$ is a noticeable exception, with oak having a higher concentration than beech over the whole time period. For Al both species have a strikingly similar profile with an increase in concentration in the last 15 years (figure 2). In sharp contrast with oak, the concentrations of $\mathrm{Ca}, \mathrm{Mg}$, $\mathrm{K}, \mathrm{Mn}$ in beech show a decreasing pattern for the whole chronology (Ca: $r=-0.81, p<0.001, \mathrm{Mg}: r=-0.26$, $p>0.05, \mathrm{~K}: r=-0.60, p<0.001, \mathrm{Mn}: r=-0.65$, $p>0.001 ; n=32)$. Mg shows a somewhat complex variation profile, with growth rings formed before 1890 and between ca.1940 and 1970 being noticeably richer in those elements than both earlier and later rings. For N, P (figure 1) and $\mathrm{Al}$ (figure 2) concentrations are roughly constant to ca 1970 , with a trend for increasing concentrations in the outer 20 annual rings.

The $\mathrm{Ca} / \mathrm{Mg}$ ratio is uniformly very low $(<5)$ over the whole time period for beech (figure 3); in oak, that ratio peaks at much higher values $(>40)$ in the outermost heartwood rings. The $\mathrm{Al} / \mathrm{Ca}$ ratio is consistently low in 


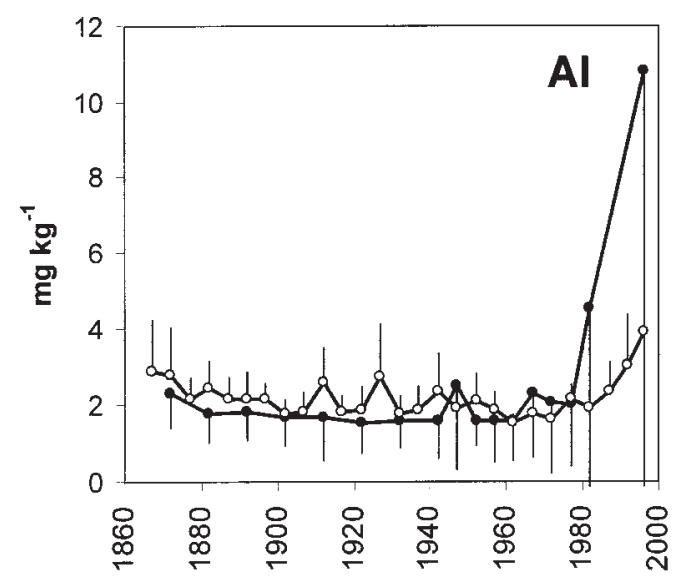

Figure 2. Wood aluminium concentrations in 5-year growth intervals in Fagus sylvatica L. (white dots) and Quercus robur L. (black dots) (mean and standard deviation over five individuals).
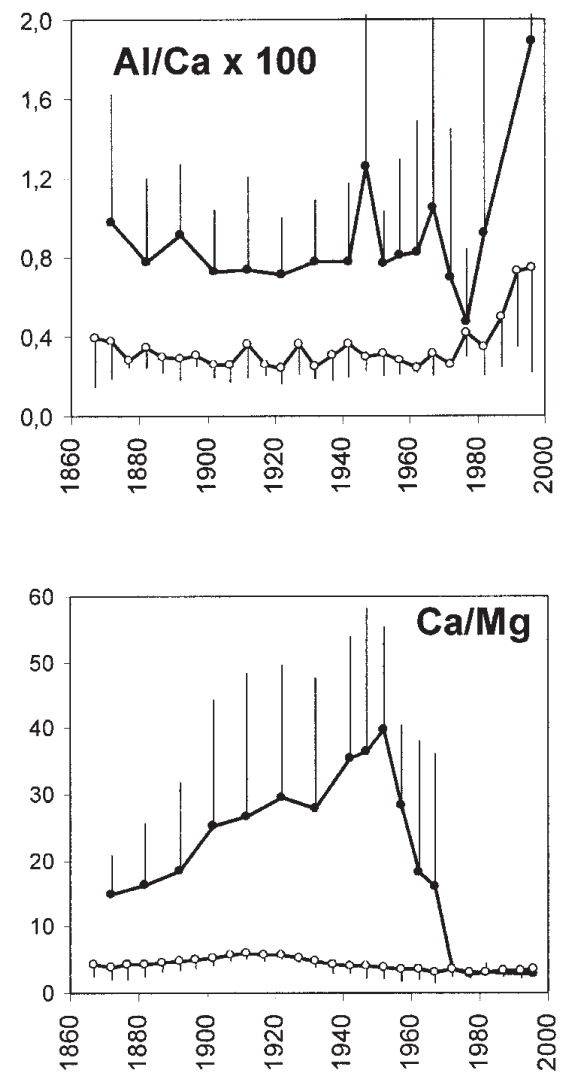

Figure 3. $\mathrm{Al} / \mathrm{Ca}$ and $\mathrm{Ca} / \mathrm{Mg}$ concentration ratio (on a mass basis) in 5-year growth intervals in Fagus sylvatica L. (white dots) and Quercus robur L. (black dots) (mean and standard deviation over five individuals). beech with only a slight increase in the last decade; it is much higher in oak, with an increase in the last five years (figure 3).

\section{DISCUSSION}

\subsection{Comparison of oak and beech}

There are striking differences in mineral element concentration profiles in the wood of oak and beech growing at the same site. In hardwoods, Taneda et al. [29] categorised nutrient concentration profiles as follows: i) a gradual decrease from pith to cambium, ii) a minimum at the heartwood/sapwood boundary region, iii) a maximum at the boundary region. $\mathrm{Ca}, \mathrm{Mn}$ and $\mathrm{K}$ in beech are representative of the first pattern, while $\mathrm{Ca}, \mathrm{Mg}, \mathrm{K}, \mathrm{Mn}$ in oak clearly belong to the second one. No element could be ascribed to the third category. In line with two previous studies $[11,18]$, our results show that pedunculate oak sapwood is markedly richer than heartwood in $\mathrm{N}, \mathrm{P}, \mathrm{K}, \mathrm{Mg}, \mathrm{Mn}$. Abrupt increases in mineral element concentrations at the heartwood/sapwood boundary are usually interpreted as resulting from nutrient resorption from senescing sapwood rings $[2,6,14,16,18,23,25$, 27, 31]. This issue will be discussed further below. Compared to three other species of Fagaceae (two Quercus and one Castanea) studied by Okada et al. [25], Fagus sylvatica is unusual in having decreasing concentrations of metals from pith to cambium. That pattern was already reported by Hagemeyer et al. [15] and by Meisch et al. [22], although in the latter study, concentration profiles were more complex, due to temporally variable atmospheric pollution. The difference in concentration profiles between Fagus and Quercus are in line with the generally accepted fact that Fagus lacks typical heartwood $[28,30]$. The profiles of $\mathrm{Ca}, \mathrm{Mg}, \mathrm{Mn}$ in Fagus are similar to those found in some species of softwoods $[16,27]$ especially those with a high moisture content in the trunk [25]. Helmisaari and Siltala [16] argue that increasing concentrations towards the pith are indicative of low mobility of the corresponding element. In spite of the lack of a clearly differentiated sapwood, beech showed an increasing nitrogen and phosphorus concentrations in the 10 to 15 outermost rings. This finding is in agreement with the higher concentrations of nitrogen incorporated in proteins in the outermost 11 rings of beech [34], most likely explained by a higher proportion of living parenchyma cells in those rings [23]. It is noteworthy that oak and beech had similar concentrations for most elements in the outermost rings. 


\subsection{Nutrient resorption in oak}

Although nutrient concentration profiles are highly species- and element-specific [6, 24, 27, 29], it appears that $\mathrm{N}, \mathrm{P}, \mathrm{K}$ and $\mathrm{S}$ most often have higher concentrations in the sapwood, in line with their metabolic role in living cells and their high mobility in xylem [9, 12, 27, 34]. By contrast, $\mathrm{Ca}, \mathrm{Mg}$ and $\mathrm{Mn}$ often have higher concentrations in the heartwood [27]. The particular pattern of element resorption found in Quercus robur in this study and by de Visser [11] and Lévy et al. [18] is strikingly similar to that reported for other species of Quercus from Northern America (Q. rubra, Q. alba, Q. coccinea: $[17$, 19, 31, 33]), China (Q. mongolica: [6]) and Japan $(Q$. mongolica, $Q$. serrata: [25]). Thus, it would appear that a high resorption of $\mathrm{Ca}, \mathrm{Mg}, \mathrm{Mn}, \mathrm{K}$, at the heartwood/sapwood boundary is a characteristic feature of most (if not all) species of Quercus.

Bamber and Fukazawa [2] argued that internal recycling of elements must reduce the nutrient demand placed on the ecosystem by large trees and this was shown to be the case for phosphorus in red spruce [10]. In that context, our results strikingly demonstrate that oak and beech, two dominant species in western European forests, have contrasting mineral nutrition strategies, with beech having much higher amounts of nutrients immobilised in boles [1]. The functional and ecological significance of that difference would deserve further investigation.

\subsection{Comparison with other sites}

Compared to published data [12, 15] beech wood from the acidic soil of the Belgian Ardennes has similar to somewhat lower concentrations of $\mathrm{Ca}$ and $\mathrm{Mg}$. In the case of oak, a detailed comparison of concentration profiles is possible with the data from a podzolic soil in the Netherlands [11] and from the clayey soils with a higher base content and a higher biological activity from NE France [18]. It appears that oak heartwood from both acidic soils (Belgian Ardennes and the Netherlands) is poorer in all elements except $\mathrm{N}$ than that from soils with a higher nutrient status. For magnesium it is interesting that concentrations in the sapwood were similar for all three sites, while concentrations in the heartwood were markedly lower in the Ardennes. This suggests that the efficiency of resorption of $\mathrm{Mg}$ was higher in the site with the lowest availability of that element, a hypothesis which would certainly deserve to be confirmed. The pattern of between site variation for $\mathrm{Al}$ is surprising, since samples from mesotrophic soils in France had ca. 4 times higher concentrations than those from more acidic soils in Belgium and the Netherlands. That discrepancy can not readily be explained and would deserve further investigation.

\subsection{Evidence for environmental change}

In a forest from NE France where recent changes of the ground flora are indicative of soil acidification and increased nitrogen fertility, Lévy et al. [18] found decreasing concentrations of $\mathrm{P}, \mathrm{K}$, and $\mathrm{Mg}$ and increasing concentrations of $\mathrm{N}$ and $\mathrm{Al}$ in the outermost 20 rings of oak heartwood. They ascribed those changes to the long-term effects of leaching of forest soil by acid rain, in line with similar previous reports in other polluted regions of the world $[4,5,20,22,24]$. In the present study, there was a systematic, statistically significant decrease of $\mathrm{Ca}, \mathrm{Mg}, \mathrm{K}, \mathrm{P}$ and $\mathrm{Mn}$ in oak heartwood, but there was no significant change in $\mathrm{Al}$ and $\mathrm{N}$ concentrations and in $\mathrm{Al} / \mathrm{Ca}$ ratio. Thus, our results can be less easily interpreted in terms of increased nitrogen status and decreased soil $\mathrm{pH}$. In particular, $\mathrm{Mn}$ concentrations in tree rings are positively correlated with the acidity of the soil solution $[13,17]$; therefore, the finding of a decrease in $\mathrm{Mn}$ is difficult to reconcile with a hypothesis of soil acidification.

Interestingly, $\mathrm{Ca}, \mathrm{Mg}$ and $\mathrm{K}$ also show a decreasing pattern in beech over the same time period. A similar pattern found in two coexisting species with contrasting wood structure could arguably point to a common environmental effect. However, as stated hereabove, decreasing cations concentrations from pith to outer heartwood (or to cambium) have been commonly observed in many different species of trees in various environmental contexts $[24,25,27,29,31]$, including beech [15] and several oak species $[6,31]$. Therefore, it is questionable whether such outwardly decreasing concentration gradients are actually indicative of cation depletion in the soil solution. Centripetal migrations of elements are one possible mechanisms explaining that concentration gradient. The "wavy" profile of $\mathrm{Mg}$ and $\mathrm{K}$ in beech, accompanied by relatively large standard deviations might indicate that such radial movements are occurring. Another explanation can lie in a systematic decrease of wood cation binding capacity (CBC) with ageing as shown by Momoshima et al. in Japanese cedar [24]. CBC has apparently never been assessed in oak and beech wood.

Increasing $\mathrm{Al}$ concentrations and $\mathrm{Al} / \mathrm{Ca}$ ratio in the wood are often regarded as reliable indicators of soil acidification because of the low mobility of $\mathrm{Al}$ in the wood $[8,9,14,21]$. Al concentrations in this study were strikingly similar in both species throughout the study period, with constant concentrations of ca. 2 ppm from 1870 to 1970 , followed by an increase up to $4 \mathrm{ppm}$ for 
beech and $11 \mathrm{ppm}$ for oak in the last 20 years. In oak, Lévy et al. [18] found regularly increasing concentration of Al throughout heartwood. In beech, Meisch et al. [22] found $\mathrm{Al}$ concentration of ca. $3 \mathrm{ppm}$ in the inner wood and an increase in $\mathrm{Al}$ concentration in the outer 20 rings, up to $30 \mathrm{ppm}$, which they ascribed to acid rain. De Visser [11] found no clear temporal trend for Al in oak. In $Q$. mongolica, Chun and Hui-yi [6] found a profile of Al quite similar to that of $Q$. robur in the present study, which they could not unequivocally ascribe to soil acidification.

In conclusion, beech and oak growing on the same soil in the Belgian Ardennes show markedly contrasting mineral element concentrations profiles in the wood, which may reflect the sharp difference in wood structure. The pattern of element resorption at the heartwood/sapwood boundary observed in oak is apparently typical for the genus Quercus. The decreasing concentration of Ca, $\mathrm{Mg}, \mathrm{K}$ in both species (except in oak sapwood) is apparently consistent with a long term process of soil acidification, possibly due to acid rain. However, the decrease in $\mathrm{Mn}$ in both species warns against a too simplistic interpretation of the data in terms of environmental change. The question whether outwardly decreasing concentrations of cations can be explained by similarly decreasing cation binding capacity of wood is currently being investigated.

Acknowledgements: We wish to thank Ir. P. Maréchal and J.-P. Dufour (Ministère de la Région wallonne, Direction générale des Ressources naturelles et de l'Environnement, Division de la Nature et des Forêts), for giving us access to the Herbeumont State Forest and advice in the selection of the studied site. Gratitude is also extended to J.-C. Moniquet, A. Demoulin and J. Vermander for assistance in the collection and preparation of wood samples. This research was supported by the Convention 2.4517.98 of the Fonds pour la Recherche fondamentale et collective (FRFC, Belgium). V. Penninckx is fellow of the FRIA (Fonds pour la formation à la recherche dans l'industrie et l'agriculture).

\section{REFERENCES}

[1] Augusto L., Ranger J., Ponette Q., Rapp M., Relationships between forest tree species, stand production and stand nutrient amount, Ann. For. Sci. 57 (2000) 313-324.

[2] Bamber R.K., Fukazawa K., Sapwood and heartwood: a review, Forestry Abstracts 46 (1985) 567-580.

[3] Barry-Lenger A., Nebout J.-P., Le chêne, Éditions du Perron, Liège, 1993.

[4] Bondietti E.A., Baes III C.F., Mc Laughlin S.B., Radial trends in cation ratios in tree rings as indicators of the impact of atmospheric deposition on forests, Can. J. For. Res. 19 (1989) 586-594.

[5] Bondietti E.A., Momoshima N., Shortle W.C., Smith K.T., A historical perspective on divalent cation trends in red spruce stemwood and the hypothetical relationship to acidic deposition, Can. J. For. Res. 20 (1990) 1850-1858.

[6] Chun L., Hui-yi H., Tree-ring analysis of Korean pine (Pinus koraiensis Sieb. Et Zucc.) and Mongolian oak (Quercus mongolica Fisch. ex Turcz.) from Changbai Mountain, northeast China, Trees 6 (1992) 103-108.

[7] Cottenie A., Verloo M., Kiekens L., Velghe G., Camerlynck R., Chemical analysis of plants and soils, Laboratory of analytical and agrochemistry, State University Ghent, Belgium, 1982.

[8] Cronan Ch.S., Grigal D.F., Use of calcium/aluminium ratios as indicators of stress in forest ecosystems, J. Environ. Qual. 24 (1995) 209-226.

[9] Cutter B.E., Guyette R.P., Anatomical, chemical and ecological factors affecting tree species choice in dendrochemistry studies, J. Environ. Qual. 22 (1993) 611-619.

[10] Dambrine E., Le Goaster S., Ranger J., Croissance et nutrition minérale d'un peuplement d'épicéa sur sol pauvre. II Prélèvement racinaire et translocation d'éléments minéraux au cours de la croissance, Acta Oecologica 12 (1991) 791-808.

[11] De Visser P.H.B., The relations between chemical composition of oak tree rings, leaf, bark, and soil solution in a partly mixed stand, Can. J. For. Res. 22 (1992) 1824-1831.

[12] Fiedler H-J., Höhne H., Vorkommen und Gehalt der Makronährstoffe in Waldbaümen, Wiss. Z. Techn. Univers. Dresden 14 (1965) 989-999.

[13] Guyette R.P., Henderson G.S., Cutter B.E., Reconstructing soil $\mathrm{pH}$ from manganese concentrations in treerings, For Sci. 38 (1992) 727-737.

[14] Hagemeyer J., Monitoring trace metal pollution with tree rings: a critical reassessment, in: Plants as biomonitors, Indicators for heavy metals in the terrestrial environment, VCH-Verlag, Weinheim, 1993.

[15] Hagemeyer J., Kamradt B., Schäfer H., Schlagintweit K., Verlage L., Breckle S.-W., Saisonale Schwankungen der Elementgehalte und Histologie des Kambiums von Buchenholz in Nordrhein-Westfalen, Allg. Forst. Zeitsch. 29-30 (1989) 769-772.

[16] Helmisaari H.-S., Siltala T., Variation in nutrient concentrations of Pinus sylvsetris stems, Scand. J. For. Res. 4 (1989) 443-451.

[17] Kashuba-Hockenberry L.A., DeWalle D.R., Dendrochemical response to soil liming in scarlet oak, Can. J. For. Res. 24 (1994) 564-567.

[18] Lévy G., Bréchet Cl., Becker M., Element analysis of tree rings in pedunculate oak heartwood: an indicator of historical trends in the soil chemistry, related to atmospheric deposition, Ann. Sci. For. 53 (1996) 685-696.

[19] Majumdar S.K., Halma J.R., Cline S.C., Rieker D., Daehler C., Zelnick R.W., Saylor T., Geist S., Tree ring growth and elemental concentration in wood cores of oak species in 
eastern Pennsylvania: possible influences of air pollution and acidic deposition, Environmental Technology 12 (1991) 41-49.

[20] Mc Laughlin D., A decade of forest health monitoring in Canada: evidence of air pollution effects, http://www.cciw.ca/eman-temp/reports/publications/Forest/ main.html.

[21] Mc Laughlin S.B., Wimmer R., Calcium physiology and terrestrial ecosystem processes, New Phytol. 142 (1999) 373-417.

[22] Meisch H.-U., Kessler M., Reinle W., Wagner A., Distribution of metals in annual rings of the beech (Fagus sylvatica) as an expression of environmental changes, Experientia 42 (1986) 537-542.

[23] Merrill W., Cowling E.B., Role of nitrogen in wood deterioration: amounts and distribution of nitrogen in tree stems, Can. J. Bot. 44 (1966) 155-1580.

[24] Momoshima N., Eto I., Kofuji H., Takashima Y., Koike M., Imaizumi Y., Harada T., Distribution and chemical characteristics of cations in annuals rings of japanese cedar, J. Environ. Qual. 24 (1995) 1141-1149.

[25] Okada N., Katayama Y., Nobuchi T., Ishimaru Y., Aoki A., Trace elements in the stems of trees VI. Comparisons of radial distributions among hardwood stems, Mokuzai Gakkaishi 39 (10) (1993) 1119-1127.

[26] Penninckx V., Meerts P., Herbauts J., Gruber W., Ring width and element concentrations in beech (Fagus sylvatica L.) from a periurban forest in central Belgium, Forest Ecol. Manage. 113 (1999) 23-33.

[27] Riitters K.H., Ohmann L.F., Grigal D.F., Wood tissue analysis using an element ratio technique (DRIS), Can. J. For. Res. 21 (1991) 1270-1277.

[28] Schweingruber F.H., Trees and wood in dendrochronology, morphological, anatomical, and tree-ring analytical characteristics of trees frequently used in dendrochronology, Springer-Verlag, Berlin, 1993.

[29] Taneda K., Ota M., Nagashima M., The radial distribution and concentration of several chemical elements in woods of five japanese species, Mokuzai Gakkaishi 32 (10) (1986) 833-841.

[30] Tessier Du Cros E., Le hêtre, INRA, Paris, 1981.

[31] Wardell J.F., Hart J.H., Radial gradients of elements in white oak wood, Wood Sci. 5 (1973) 298-303.

[32] Weissen F., Van Praag H.J., André P., Maréchal P., Causes du dépérissement des forêts en Ardenne : observations et expérimentation, Silva Belgica 99 (1992) 9-13.

[33] Woodwell G.M., Whittaker R.H., Houghton R.A., Nutrient concentrations in plants in the Brookhaven Oak-Pine forest, Ecology 56 (1975) 318-332.

[34] Ziegler H., Biologische Aspekte der Kernholzbildung, Holz als Roh- und Werkstoff 26 (1968) 61-68.

To access this journal online: www.edpsciences.org 